\title{
Twenty-Five Years and Still Recovering: A Brief Reflection on NAFTA's Impact on Southside Virginia
}

\author{
Sandra Via
}

Reflecting on the 25th anniversary of the enactment of the North American Free Trade Agreement (NAFTA), I cannot help but think back to my childhood in Southside, Virginia. I grew up in an area that was once considered the hub of the furniture and textile industries. While Martinsville, Virginia and the surrounding area of Henry County was never a metropolis, it was a vibrant community and small city that provided the workforce that built companies such as Bassett Furniture, Hooker Furniture, American Furniture, Fieldcrest Cannon, Bassett-Walker, Sara Lee, Dupont, Tultex, and several others. It was impossible to live in that area and not have family members and close friends who worked in one of those factories. For instance, many of my family members started working for Bassett Furniture in some capacity while in high school and planned for that job to be their lifelong career. One family member was instrumental in the establishment of the Bassett Furniture motor pool, which he managed until his retirement. Another was an executive assistant to one of the Bassett family members. These family members were lucky and were able to retire before the effects of NAFTA and neoliberal globalization started to take hold. Other family members and close family friends, however, were not so lucky. Eventually, there came a time when people in that area wondered week to week, or even day to day, whether they were going to be part of the next round of factory layoffs and closures. Unfortunately, the effects of NAFTA's push to increase global competition and deregulation ravaged this once prosperous Southern community.

Even before NAFTA was enacted, Southside was beginning to experience the effects of neoliberal globalization. Neoliberal globalization is characterized by policies that promote deregulation, privatization, and commodification of everything in favor of expanding free and open markets and increasing unfettered capital accumulation for corporations (Harvey 2005). In other words, neoliberal globalization is a form or "brand" of economic globalization in which corporate values are prioritized above all other forms of values at the expense of the social welfare of citizens and laborers (Agger and Luke 2012; Cavanagh and Mander 2004: 33). David Harvey notes that as neoliberalism becomes entrenched in the neoliberal state, politicians engage in an all-out assault on all forms of social solidary, particularly trade unions (2005). By eliminating the collective bargaining capacity of unions, economic elites are further able to increase their own class power and promote the profit of the corporation over the welfare of the worker. As political elites launch attacks on unions, corporations are further emboldened by the increased mobility of capital and the physical plants provided by neoliberal globalization policies, such as NAFTA. When workers attempt to unionize employers "routinely threaten that if workers vote for a union, the owners will close the plant and move it abroad, and this is a powerful weapon in the assault on unions" (Clawson 2003: 143). Therefore, unions at many manufacturing plants did not question decisions or complain about low wages for fear of losing their jobs.

In order to open markets, tariffs are reduced or eliminated completely and deregulation in manufacturing occurs (Harvey 2005; Cavanagh and Mander 2004). With the enactment of NAFTA, "unregulated consolidation in the retail sector was driving clothing prices down," which allowed for cheap textiles to be pumped into the American economy (Collins 2002: 152). As a result, American textile mills had to find ways to produce lower quality, cheap 
goods, and reduce the costs of productions. These new challenges were further complicated when NAFTA was ratified, signed into law, and implemented in January 1994. Proponents of NAFTA only focused on the elimination of trade barriers and tariffs on all goods between Mexico, Canada, and the United States, which they believed would "produce nothing short of an economic renaissance in North America" (Martin 1993: 240). Opponents warned that the agreement would "cost hundreds of thousands of American jobs as manufacturers relocate plants south of the border, where cheap labor could make goods for duty-free export to the United States" (Gerstenzang 1993: para. 3). Corporations ensured government officials that they would not send jobs overseas or south and would keep jobs in manufacturing towns (Gerstenzang 1993). This was hard to believe considering the low cost of labor in Mexico. As Christopher J. Martin points out, Mexican manufacturing labor in 1991 averaged an hourly rate of \$2.17 while American manufacturing workers averaged \$15.45 an hour (Martin 1993: 241). Furthermore, foreign investors had already begun to take advantage of Mexico's newly instituted maquiladora program, which employed manufacturer workers at an average of $\$ 1.25$ an hour (Martin 1993: 242). In other words, there did already exist incentives for U.S. manufacturers to relocate their factories to impoverished maquiladora towns. They could reduce their costs and increase profits by relying on cheap labor in Mexico. NAFTA's enactment provided even more incentive to relocate because it eliminated additional tariffs and eased rules for foreign direct investment in addition to available cheap labor (Martin 1993; 242).

Unsurprisingly, after NAFTA's implementation, these companies eliminated jobs and moved textile and apparel manufacturing plants across the border where they could exploit low-wage workers. Neglecting the social responsibility that these corporations had to the workers that had built their companies and made their products world renown, manufacturers closed their doors leaving workers without any other job prospects. The workers in these locally grown plants had perceived that an implied contract, which can be a psychological and/or social contract, had been formed between them and their employers (Van Buren 2000). The psychological contract establishes unwritten terms and agreements between the employees and the employer that establish conditions or perceptions about ethical standards of fairness and morality that employers should follow, which in Martinsville and Henry County, included loyalty to the workers and community in which the corporations were founded (Van Buren 2000: 208). The social contract supplements the psychological contract through the establishment of unwritten ground rules and local values on economic morality that are expected for the corporation to be a good citizen within the community (Van Buren 2000; 208). As longstanding “members" of the community, manufacturers in Martinsville and Henry County were expected to keep these implied contracts and look out for the common good of the community as a whole and its employee stakeholders. The implied contract was even more important to these workers as unions were losing their bargaining power in the area. Such contracts emphasize "the conduct of business is not a purely private matter; businesses serve, and are thus accountable to, the common good" (Van Buren 2000: 213). Many workers in the Martinsville and the surrounding area felt betrayed when these implied contracts were broken as layoffs continued to occur and manufacturing was relocated in favor of cheap labor and profits over the wellbeing of the local community.

Some individuals did find jobs in other manufacturing plants in the area, only to lose those jobs as the carnage of NAFTA continued to make its way through Southside. As one factory closed, workers moved to other local factories, which in turn closed. This carnage was most visible when Tultex, an apparel manufacturer and one of the largest employers in the city of Martinsville, abruptly filed bankruptcy and immediately closed the factory in December 1999. Approximately 2,000 workers were left without jobs (U.S. General Accounting Office 2001: 9). In a town of approximately 15,000 people, this had a devastating impact on the population (U.S. Census Burearu 2003: 3). The city's unemployment rate skyrocketed from $9 \%$ to $20 \%$ after Tultex's closure (U.S. General Accounting Office 2001: 10).

To further exacerbate the situation, Tultex’s bankruptcy filing resulted in a default on over $\$ 1$ million in property taxes, leaving the local taxpayers to absorb the loss. The closure of Tultex also meant that the city of Martinsville would lose approximately an additional “\$700,000 annually in tax revenues and nearly $\$ 600,000$ in water fees," which the city had come to rely. (Collins 2002: 156). Not only did citizens lose their jobs, health insurance, pensions, vacation days, and any other benefits they may have accumulated while working at Tultex, those that lived in the city now had to compensate for the loss of tax revenues through increased water and sewage bills (U.S. General Accounting Office 2001: 11). The city and state had to rapidly find a way to deal with the overwhelming demand for local social services and the influx of unemployment claims (Collins 2002: 156). The reduction in tax revenues also meant fewer funds for local schools. Within five years of Tultex's closure, Henry County was forced to merge its 
four high schools into two schools in order to reduce operating costs and avoid the elimination of course offerings for students (Allen 2004). Even more devastating side effect of these manufacturing closures in the region was, and still is, an increase in drug use. In order to cope with job losses and poverty, some people in the area turned to "drugs, alcohol, and suicide" (Knowles 2019: para. 20). In particular, opioid addiction and overdoses in the area have skyrocketed and as of November 2018, Martinsville and Henry County rank number one in Virginia for emergency visits due to opioid overdoses (Collins 2018: para. 1). Many people in the area are not able to get jobs or keep them because they are unable to pass drug tests (Knowles 2019: para. 26). Therefore, local officials must continue to contend with unemployment and a declining population, while also finding ways to fight a growing opioid crisis.

Some individuals that decided to remain living in the county or city looked for jobs in nearby areas or across the North Carolina border. Others had no other option but to leave their homes and uproot their families in search of new job opportunities. This was particularly devastating for people who had been born and raised in Martinsville and Henry County but were now faced with the choice between staying in a place that had been their ancestral home but offered no economic security or moving to a new, alien location that offered some prospect of a job and economic security. At the same time, relocation meant figuring out how to take on the cost of moving, including selling their house in an area that was saturated with the houses of others who were relocating. For example, local real estate agents reported that following Tultex's closure the housing market in the area declined because homeowners were leaving the area and there were no buyers for the homes (U.S. General Accounting Office 2001: 64).

A shimmer of hope was found by some workers that took advantage of the Trade Adjustment Assistance (TAA) and the NAFTA-Trade Adjustment Assistance (NAFTA-TAA), which are programs designed to provide financial assistance and job training to workers that are displaced due to foreign trade and increased imports (U.S. General Accounting Office 2001: 5). The TAA program was initially created by the Trade Expansion Act of 1962 and later modified by the Trade Act of 1974, due to the opening of foreign markets and increased global competition that accompanied free trade policies (U.S. General Accounting Office 2001: 5). Policymakers knew that free trade policies would negatively impact U.S. manufacturing workers. Therefore, the TAA was created as a means to assist the workers that lost their jobs for "greater good" (Vijaya 2010: 2). In other words, policymakers created the TAA as a means of promoting corporate growth and a neoliberal economic agenda, while also trying to alleviate their own guilt about putting American workers out of a job. Anticipating layoffs resulting from shifts in production to Canada and Mexico due to NAFTA, the NAFTA-TAA was by the North American Free Trade Agreement Implementation Act of 1993 (U.S. General Accounting Office 2001: 5; Vijaya 2010: 2).

Under the TAA and NAFTA-TAA workers in Martinsville and Henry County that had lost their job in either the textile, apparel, or furniture industry due to NAFTA or the increase of Chinese imports could theoretically receive financial assistance beyond unemployment with funds to seek job training. However, not everyone in Martinsville and Henry County that lost their job took advantage of these assistance programs. First, in order to even qualify for TAA benefits, a group of at least three individuals from the same place of employment has to jointly submit a petition the Department of Labor stating that they lost their jobs due to the import of goods or the shift in global production due to NAFTA (Vijaya 2010: 2). These individuals must then wait for their petition to be approved before they can apply for any benefits. Once those individuals were certified, however, that still did not mean that they were able to access the benefits of the TAA programs. According to a 2001 GAO report, residents of Martinsville and Henry County faced a number of obstacles in either obtaining or using TAA and NAFTA-TAA programs: many workers did not have a high school education and needed to obtain a GED before enrolling in a training certification or community college program; family responsibilities made it impossible to go to or continue schooling without income assistance; there was a lack of stable funding; applying for benefits was often difficult and confusing; and training programs did not align with enrollment deadlines (U.S. General Accounting Office 2001: 15-19). Not mentioned in this report is the fact that many people that did try, and are still trying, to take advantage of the TAA are not able to complete the job training programs because they do have the necessary skills needed to be successful in a college course that is most likely driven by technological changes. Others lost their jobs only years away from retirement or during mid-life. These individuals believe they are too old to be hired by other employers. Even today, people in the area still feel like they have no options after losing their jobs later in life. In 2016, one local told a BBC reporter, "I got to the point where here I am, 58 years old now, nobody will say this, but nobody wants to hire me at this age" (Lussenhop 2016: para. 38). Not only do these obstacles reflect the failures and flaws inherent in the TAA and NAFTA-TAA, but also the lack of understanding and disconnection from the populations and communities impacted by NAFTA by the political elites crafting and implementing these programs. Policymakers 
ignorantly assume that these workers, many of whom never graduated from high school, could understand the complicated process of obtaining benefits or had the financial means even with some assistance from the program to support themselves and their families while attending a community college or trade program on a full or part-time basis. Individuals that did go back to school and obtain some new form of job training found that jobs were still not available to them despite their newly acquired job skills and education. Some did benefit and find jobs, particularly those that were able to complete their educational training or acquired skills in education or health sectors, which have become rallying sectors for economic development in the area (Dorsey 2017: para. 22).

Martinsville and Henry County have experienced some recovery in recent years. According to the Bureau of Labor Statistics, unemployment in Martinsville was 4.1\% in December 2018, and 3.3\% in Henry County (U.S. Bureau of Labor Statistics 2019). This is a marked improvement from the $20 \%$ unemployment rate Martinsville saw after the collapse of Tultex. However, the decline in unemployment is in part due to many individuals are no longer trying to find work (Lussenhop 2016). The jobs left in the region are often low-skill and minimum wage positions at discount chain retailers, such as Dollar General or Family Dollar (Macy 2014; 325). The population in the area has also decreased to just fewer than 13,000 people in 2018 (U.S. Census Bureau 2018), which ultimately contributes to a decline in unemployment. The decline in population is due in part to people relocating to find work as previously mentioned. At the same time, there has been an increase in "brain drain" in the region. Those that are highly skilled leave or originally from the area do not return after attending college instead of seeking to find jobs in locations with a variety of high-skilled jobs, attractions, and entertainment.

Local officials are trying to revitalize the area by trying to entice businesses to the area and through the promotion of tourist attractions such as NASCAR races at the Martinsville Motor Speedway, the Virginia Museum of Natural History, and surrounding national parks. The area has experienced some newfound attention due to Beth Macy's Factory Man, which chronicles the life John Bassett III while also shedding light on some of the individuals who worked and continue to work in the furniture manufacturing factories (Macy 2014). However, that attention is not enough to bring it back to its glory days, or even the days that I remember as a child. Even though Martinsville and surrounding areas are beginning to "recover" from the losses inflicted by NAFTA, the area continues to feel its effects and may feel those effects once again with the enactment of the recently introduced United State-MexicoCanada Agreement (USMCA).

\section{References}

Agger, Ben and Timothy W Luke. 2012. "Occupy Globalization." Fast Capitalism 9.1. Retrieved April 29, 2019 (http://fastcapitalism.com).

Allen, Mike. 2004. "School System Merger Advised." The Roanoke Times. June 10, Retrieved April 30, 2019 (https:// www.roanoke.com/webmin/news/school-system-merger-advised/article_822dbe1d-be58-5763-b49c-c006b634b92f.html).

Cavanagh, John and Jerry Mander, eds. 2004. Alternatives to Economic Globalization: A Better World is Possible. San Francisco: Berrett-Koehler Publishers.

Clawson, Dan. 2003. The Next Upsurge: Labor and the New Social Movements. Ithaca: Cornell University Press.

Collins, Jane L. 2002. "Deterritorialization and Workplace Culture.” American Ethnologist 29(1): 151-171.
Collins, Paul. 2018. "Opioid Overdoes Numbers Continue to Climb in Martinsville, Henry County.” Martinsville Bulletin. November 2, Retrieved April 29, 2019 (https://www.martinsvillebulletin.com/news/opioid-overdose-numbers-continue-to-climb-in-martinsville-henry-county/article_6c31055ede3b-11e8-b6ca-231509973b98.html).

Dorsey, Barry. 2017. "Looking Back on Southside: Three Transitions." Martinsville Bulletin, December 24, Retrieved February 25, 2019 (https://www.martinsvillebulletin.com/ news/looking-back-on-southside-three-transitions/article_40fdd106-e930-11e7-a12a-6f4f75b1b579.html).

Gerstenzang, James. 1993. "With NAFTA, Analysts see Winners, Losers.” Los Angeles Times, November 14, Retrieved February 25, 2019 (http://articles.latimes. com/1993-11-14/news/mn-56937_1_nafta-s-winners).

Harvey, David. 2005. A Brief History of Neoliberalism. New York: Oxford University Press. 
Knowles, Amie. 2019. "2 Keys to Finding a Good Job in Martinsville Area: Get Trained, Get Straight.” Martinsville Bulletin. March 4. Retrieved April 29, 2019 (https://www. martinsvillebulletin.com/news/local/keys-to-finding-a-goodjob-in-martinsville-area-get/article_479c2169-417f-56c8-ae188604c6699079.html).

Lussenhop, Jessica. 2016. "US Election: Under the Skin of Trump Country.” BBC News, July 15, Retrieved February 25, 2019 (https://www.bbc.com/news/world-us-canada-36752237).

Macy, Beth. 2014. Factory Man: How One Furniture Maker Battled Offshoring, Stayed Local-and Helped Save an American Town. New York: Little, Brown and Company.

Martin, Christopher J. 1993. "The NAFTA debate: Are Concerns About U.S. Job Migration to Mexico Legitimate?” Employee Relations Law Journal 19(3): 239-250.

U.S. Census Bureau. 2003. Population and Housing Counts: Virginia: 2000: 2000 Census of Population and Housing. Washington, D.C.: U.S. Department of Commerce. Retrieved April 30, 2019 (https://www.census.gov/prod/cen2000/ phc-3-48.pdf).
U.S. Census Bureau. 2018. QuickFacts: Martinsville, Virginia. Washington, D.C.: U.S. Department of Commerce. Retrieved April 30, 2019 (https://www.census.gov/quickfacts/ martinsvillecityvirginiacounty).

U.S. Bureau of Labor Statistics. 2019. Local Area Unemployment Statistics Map: Counties. Washington, D.C.: U.S. Department of Labor. Retrieved February 28, 2019 (https://data.bls.gov/ map/MapToolServlet?survey=la\&map=state\&seasonal=s).

U.S. General Accounting Office. 2001. Trade Adjustment Assistance: Experiences of Six Trade- Impacted Communities: Report to the Chairman and Ranking Member, Committee on Finance, U.S. Senate. Washington, D.C.: U.S. General Accounting Office.

Van Buren, Harry J. 2000. "The Bindingness of Social and Psychological Contracts: Toward a Theory of Social Responsibility in Downsizing." Journal of Business Ethics 25: 205-219.

Vijaya, Ramya M. 2010. "Broken Buffer: How Trade Adjustments Assistance Fails American Workers.” Dēmos. 
